\title{
WORLD EXPERIENCE IN FINANCING INNOVATIVE SMALL BUSINESSES
}

\author{
Borys Shuba ${ }^{1}$, Artur Sotskyi
}

\begin{abstract}
The aim of the article is to study and generalize world experience in financing innovative small businesses to determine the areas of improvement of financing domestic small and medium innovative enterprises within the framework of state innovative policy. The subject of the study is the world experience in financing innovative small businesses. Methodology. The study is based on the comparative analysis of the systems of financing innovative small businesses in Ukraine and foreign countries. The analysis of specificities of financing innovative small businesses in Germany, the United States, the United Kingdom, China, Japan, Spain, Belgium, and in some other countries enables to determine the advantages and disadvantages of different systems of financing innovations in small businesses. Comparative legal study of certain provisions of Ukrainian legislation enables to determine the potentials and application limits of positive foreign experience in the specified sphere. The results of the study revealed that the world economy has accumulated significant experience in the formation and development of a financial support system for innovation, which includes various levers to intensify intellectual creativity. The maximum effect from their use would be ensured by the systematic consideration of all financial instruments, integration with elements of other subsystems of the national innovation system. Practical implications. The experience of developed economies and the analysis of the current state of financing innovation activity in Ukraine suggest that to create a developed layer of industrial and innovative small businesses, which will become the main consumer and producer of innovations, Ukraine should apply the entire complex of organizational, regulatory, financial, and other measures. While the whole complex of issues related to the development of innovation in Ukraine is of great importance, the problem of forming an active demand for innovation should be put into the first place. Relevance/originality. The analysis of the global experience of financing innovative small businesses is the basis for developing the most promising areas for the improvement of domestic legislation in this sphere.
\end{abstract}

Key words: small businesses, innovations, financing for innovation, investments, public support for innovations.

JEL Classification: L21, H25, E22

\section{Introduction}

In order to stabilize and accelerate socio-economic development, Ukraine focuses on the study and generalization of world experience in using the sources of economic growth. In a post-industrial society, the achievement of positive results largely depends on the approach to innovation. This ensures the maximum effect from its functioning and realization to full potential the modern purpose of innovation as a key factor in economic development.

In Ukraine, over the past 20 years, science and innovation have low competitiveness in the international market. For example, in 2015, about $\$ 530$ million was spent on research. It is approximately 521 times less than in the United States, 32 times less than in Germany, 24 times less than in England, 23 times less than in France. Sweden, with a population of almost 5.5 times less than in Ukraine, spends 26 times more money on science than Ukraine. Such state of affairs does not promise the increasing competitiveness of Ukrainian goods in world markets, and even more, the creation of a special product that would provide the country with absolute advantages.

The financial subsystem is an integral part of the national innovation system of the state. Considering the global experience of financial support for innovation in the domestic management practice will contribute to achieving the goals of national socio-economic development, realizing and increasing competitive advantages, renewing gradually lost positions in the global innovation space, which determines the relevance of the study.

From different perspectives, the issue of financial support for innovation development is considered in the works

\footnotetext{
Corresponding author:

${ }^{1}$ Oles Honchar Dnipro National University, Ukraine.

E-mail: schuba@schuba-legal.de

${ }^{2}$ Chernivtsi Institute of International Humanitarian University, Ukraine.
} 
of domestic and foreign scientists, such as L. Antoniuk, M. Haman, V. Heiets, N. Ivanova, N. Kazakova, B. Kvasniuk, B. Lundvall, R. Nelson, A. Poruchnyk, V. Savchuk, V. Seminozhenko, L. Fedulova, K. Freeman et al. The works of these scholars form the basis for further developments and the theoretical basis of the study.

The aim of the article is to study and generalize world experience in financing innovative small businesses to determine the areas of improvement of financing domestic small and medium innovative enterprises within the framework of state innovative policy.

\section{Presentation of the main material}

Innovation development today is recognized as the most promising way to create a highly efficient modern economy in the vast majority of countries in the world. Many countries have already made positive progress by moving towards the creation of post-industrial economies.

However, over the last two decades, Ukraine has done little innovations. In Ukraine, the innovation process is under construction and requires new approaches. Some attempts to accelerate this process are not successful enough, although the state declares its intentions in legal regulation.

In particular, the main principles of state innovation policy in Ukraine are:

- an innovative model of Ukrainian economy's development;

- determination of state priorities of innovative development;

- formation of the regulatory framework for innovation activity;

- creation of conditions for preservation, development, and use of domestic scientific-technological and innovative potential;

- ensuring the interaction of science, education, production, finance and credit in the development of innovation activities;

- effective use of market mechanisms to promote innovation, support for entrepreneurship in science and technology;

- application of measures in support of international scientific and technological cooperation, technology transfer, protection of domestic products in the domestic market and its promotion to the foreign market;

- financial support, implementation of favourable credit, tax, and customs policy in innovation activity;

- assistance in the development of innovative infrastructure;

- informational support for subjects of innovative activity;

- training of personnel in innovation activity (On Innovation Activity).

To ensure the development and effective functioning of the system of information and analytical support for the implementation of state innovation policy and monitoring of the state of innovation economic development, it is necessary:

- to improve the mechanism of monitoring the state of innovation development of the economy;

- to implement an analysis of the effective application of innovation public support and encouragement mechanisms, in particular, in comparison with similar mechanisms used in other countries;

- to ensure the dissemination of information on the state of innovation activity and promising domestic developments to attract potential investors and consumers;

- to intensify public discussion on the issues of the formation and implementation of state innovation policy, etc. (The Cabinet of Ministers of Ukraine).

Without small innovation businesses, a market-driven, innovative economy cannot function and develop. In developed countries, small innovative businesses influence the growth rate of the economy, the structure and quality of the gross national product.

The crisis of 2008-2009 has markedly influenced the development of innovative small business financing and the global economy, in general. Worldwide banking systems have limited lending, consequently, because of credit risks the stimulation of small businesses has been reduced, as well as demand for them has been lost. Therefore, having lost its influx of new investments and liquidity, small innovative businesses look for new sources of foreign and private capital investors and partners through various financial instruments.

The small business support system in Europe traces its origin from the 70 s of the XX century. At that time, in order to eliminate administrative barriers, European countries introduced changes in value-added tax and adjustment of financing terms. Moreover, the European Charter for Small Enterprises was also developed; this document gave carte blanche for the implementation of small business support projects (Yevropeiska khartiia malykh pidpryiemstv). To date, financing of activities aimed at supporting small business innovation comes from the EU Structural Funds, such as European Regional Development Fund, European Social Fund, that greatly help small enterprises survive the stagnation phenomena of the post-crisis period.

It is believed that the level of small business development determines the development of the economy in total. For example, there are at least 30 entrepreneurs per 1000 citizens in the EU member states. In the EU, small enterprises are up to $90 \%$ of the total number of enterprises (Malyi biznes: kreditovaniye malogo biznesa).

Therefore, nowadays the most promising sphere of small businesses is innovation, which comprises the intellectual property market. The main condition for the successful functioning of this market is capitalization of intangible assets in the form of intellectual performance. 
Various national experiences can demonstrate the conditions for the transition to an innovative economy through financing innovative small businesses.

Since the 1960s, Japan has been the first to capitalize intangible assets of its enterprises through the intellectual property market, due to buying abroad the right to the results of intellectual property rights protected by patents and, following their re-evaluation, transforming them in intangible assets of greater value. In the 90s, having significantly improved Japanese experience, the USA successfully applied it. Currently, most countries plan capitalization of intangible assets, subject to depreciation. In the US, intangible assets are depreciated over a period of up to 40 years.

China demonstrates effective business development based on the commercialization of intellectual property. For example, the Industrial Park (Suzhou, PRC), established in April 2000, occupies 61 hectares; more than 1 million square meters provide 10,000 people with jobs with an investment of over 4 billion yuan in this period. The secret of such success is in the state strategy "To the innovation economy through the market of intellectual property" in each concrete project. In this case, the main link between the university (the centre for generating ideas), production (where these ideas are being tested), and the management centre (where these developments are implemented on a commercial basis in the real economy) is a company that provides a range of services in intellectual property. As a result, one municipal city in the PRC has about 25,000 patents, and one medium-sized Chinese telecommunication firm has 60 patents and 1500 know-how, accounting for up to $40 \%$ of its annual revenue. The structure of public expenditures on transforming small business intelligence into an intangible asset, involved in the economy, finances, research and development in China, Great Britain, France, and other countries, is from 60 to $80 \%$.

In the USA, innovative small business financing is implemented effectively. For example, in the precrisis years (2008-2009), for direct and guaranteed loans, the US Small Business Administration provided entrepreneurs for innovative projects with 550 thousand dollars in two stages for the development of risky projects, further involving private capital. Today, $40 \%$ of the US economy is an innovative economy. In the United States, a federal agency, the US Small Business Administration, operates with offices in all states. The agency facilitates lending with guarantees, as well as grants and loans to innovative small business entrepreneurs using own means through various public programs that allow financing the development of small businesses. Under programs, such as Small Business Investment Company, Secondary Loan Market, License Development Companies, Granting of Warranties and several other, the state provides small innovative enterprises with financial support in the form of share capital, loans, investment-grade bonds; enables small business lenders to improve capital liquidity through the sale some of their loans to investors; ensures their financing at fixed rates for scaling up and modernization; enables innovative small entities without collateral for a commercial bank to receive guarantees, warranties. In the United States, small businesses have begun to engage in state support earlier than in other countries through government contracts, sources of partial financing, low taxation, direct and guaranteed loans, and so on. In 2010, the United States allocated about $\$ 30$ billion to provide targeted loans for small businesses, which created 1.5 million new jobs, including a quarter of all spending in support of innovation in small businesses. The US Congress considers abolishment of all taxes on capital gains, levied on small enterprises, and controls the proportion, according to which small enterprises, including enterprises for the creation of intellectual property, should receive $23 \%$ of US public orders. Small enterprises are subject to special tax privileges, for example, a "first-year bonus," that is, the tax is paid not from the total but from half of the taxable base. Under the program of financial and credit assistance, the Small Business Administration guarantees repayment at a government expense of up to $90 \%$ of the value of loans and credits. For small business direct lending, the Administration has the right to set their maturity up to 15 years. The experience of the US proves the effectiveness of support that enables to involve bank loans in innovative small businesses by guaranteeing lending.

In contrast to the United States and other countries, China uses the generalized experience of integrating small businesses in the global community, but has programs for the country's economic development, including the development of small innovative businesses by 2020, 2050 to restructure this sphere and involve new financial development mechanisms, successfully approbated in other countries of the world. The key to China's small business development is to provide equal opportunities for all small enterprises in investing, lending, improving production, creating and commercializing intellectual property. China has established public funds to support and develop entrepreneurship, financed by public budget funds. The Chinese Centre for Business Cooperation and Coordination is engaged in creating special conditions for the cooperation of Chinese and foreign organizations for supporting small businesses, studying world experience. Over the past eight years, China has rapidly increased the number of small enterprises, including innovation, which provided significant budget revenues to the state treasury. In China, in small businesses, 60\% of the able-bodied population of the country work (Razvitie ekonomiki Kitaia).

According to the similarity of the forms and financial mechanisms of small business development in China, the USA and other countries, in Japan, the Small and Medium Enterprise Insurance Corporation and Credit Guarantee Association have been set up to facilitate 
procedures for obtaining loans for small innovation business entrepreneurs. Japan's financial policy provides for the status of small enterprises and provides them with the benefit rates, according to the type of activity, regulating the market value of products produced by restrictions on reduction/increase. In the case of overpricing or unjustified discounts, small business entities are deprived of the right to operate.

In Singapore, where offices of more than 3,000 companies in the world are located, financial innovation infrastructure for small businesses is well developed. Innovative small businesses are subject to a preferential tax law that allows attracting foreign capital and investments into the country. There is also no duty on remittances, while investments in the economy are guaranteed, and a large number of credit programs for small businesses are implemented, including special loans, subsidies, and credit risks, while lending rates are constantly decreasing (Ekonomika $\mathrm{v}$ Singapure: znachenie i rol malogo predprinimatelstva). The Singapore government, interested in supporting small innovative businesses to compete in the international market, has managed to create an innovative economy. The agency "Spring," organized in support of entrepreneurship, is engaged in the development and implementation of programs for promoting small businesses. In Singapore, active financial support has contributed to the existence of about 140,000 small and medium enterprises, which cover almost $90 \%$ of all enterprises in the country. According to Studies conducted by CNN Time Warner Group, Singapore ranks fifth in the world in the development of small businesses, has a branched innovation and actively integrates into other countries.

In Spain, the program for small business development, financing and technical support is based on European programs that have spread to European countries, including Britain, Germany, and France. In financial support, Spain gives preference to innovative small enterprises involved in the country's social policy, as well as the development of territories with low economic indicators (Maloe predprinimatelstvo i biznes v Ispanii). An interesting feature of small business development in Spain is the fact that both Spanish citizens and foreign citizens (non-residents) obtain a license and register their own businesses in less than 24 hours. Various organizations and funds, such as associations for supporting small businesses in the European Union, the State lending institution of the country and mutual funding societies, which invest, finance, and provide development subsidies, assist in the acquisition of startup capital. The European Bank for Reconstruction and Development (EBRD), involving more than 60 country members, actively promotes innovative small businesses, strengthens financial institutions and financial systems, develops the infrastructure needed for small enterprises in the European Union, Central and Eastern Europe,
non-European countries through its network of local offices. With a large set of financial instruments, the EBRD provides direct financing for small and mediumsized enterprises, including under bank credit risk. At the same time, the basis of the loans provided is the ability of the project to repay the loan within the agreed period. The EBRD helps innovative small businesses gain access to financing by providing guarantees, provides investment in the form of subscriptions to ordinary and preferred shares, quasi-investing from auxiliary loans, profitable promissory notes and bonds to preferred shares subject to redemption, and through other financial support tools.

The European Union also demonstrates support of small businesses in the innovation sector. It is an economic world community, which enables to form a single internal market and to support the monetary, economic, and political alliance of countries. All EU member states have a network of small business development organizations supported by public and private sectors. The joint activities of national and supranational bodies concerning the promotion of small and medium-sized business development in the $\mathrm{EU}$ include the financial encouragement of innovative small business development using the most appropriate sources and types of financing. With over one billion euros in funding, through financial instruments, using innovation programs, the EU expects to facilitate access to funding from 300 to 400,000 small and mediumsized enterprises (Financing Programmes for SMEs).

In the EU, one of innovation development generators is Germany, which has constructed a powerful national innovation system. Thus, about $40 \%$ of the newly created value in the country falls on the innovation-intensive sectors of the economy, and $58.7 \%$ of enterprises implement product and technological innovations. Germany is the third largest exporter of high-tech products in the world market. In the global markets for aerospace, instrumental, pharmaceutical products, its share is $14 \%$, and the total turnover from trade in high-tech products is about $\$ 16$ billion. Germany is the fourth by innovation indicators and the total index of Global Competitiveness, the fifth by the number of patents, the eighth by gross research and development costs, in addition, plans to increase this figure up to $\$ 3350$ billion by 2020 .

Within the framework of the German innovation policy, the system of financial support for innovation was developed. One of their key implementation principles is the clear commitment to the objectives within the comprehensive National High Tech Strategy (HTS), which operates until 2020, and integrates strategies for 17 future areas to implement successfully new technologies. In order to implement the provisions of the HTS, state funding is used to support cluster projects, academic, university science, "main innovations." For example, according to the results of 
the competition "Germany's Leading-Edge Clusters more innovation, more growth, more employment," the 15 best clusters receive budget funding for up to 5 years of total 600 million euros. In accordance with the Covenant of Research and Innovation Support, $3 \%$ increase over the current funding of the largest academic research institutions is applied to improve the international competitiveness of German science and technology development from within existing capacities. For ten best universities with a developed system of scientific research, an additional annual budget financing of 21 million euros is conditioned by the Prospective strategies for the development of university science. Support for "key innovations," that is targeted innovation projects, is carried out in those areas of strategic research, where serious scientific developments exist and can provide a quick practical impact in key sectors of the German economy, that is, accelerate their growth, strengthen their positions in existing markets and help them develop new ones effectively. Now in Germany, six "major innovations" are implemented: electronics (within the NanoFab program) with state support of 323 million euros); automotive industry (the NanoMobil program) with budget allocations of 37 million euros; optical industry (the Nanolux program) with state participation in financing of 156 million euros; Medicine and Biotechnology (the NanoforLife Program) with state support of about 24 million euros; chemistry (the NanoChem program) with a state funding of 31 million euros; energy with the government financial participation in research of 20 million euros (Kornilova, 2014).

In France, in 1999, a law on innovation was enacted, providing for the participation of researchers on a competitive basis to start businesses. In order to promote projects in the country, there is a program for the development of incubators for small firms to get from two to three free of charge years for the use of premises, equipment, and other facilities. Significant funds are allocated by the state for technology transfer. For the payment of specialists, loans are provided, up to $50 \%$ of which are irrevocable.

The French Innovation Relay Centre (IRC France Centr'EST) operates in a regional environment where local authorities actively collaborate in promoting innovation among small and medium-sized enterprises. A basis for the marketing strategy is the centre's own service proposal "Global Time Technology Proposal," consisting of four main components: a package of technological proposals; a package of technological requests; short-, medium-, and long-term services; technology market research. This approach has proved its effectiveness in attracting clients, as evidenced by the following facts: 12 signed innovation contracts, the success of which has increased by 33\% (Doslidzhennia: obgruntuvannia napriamiv rozvytku innovatsiinoho pidpryiemnytstva z urakhuvanniam svitovoho dosvidu).
In Belgium, the innovation process is encouraged by the so-called cluster policy. According to federal law, tax liabilities for small enterprises involved in the innovation process can be reduced up to $100 \%$. In Flanders, an investment law provides for the budget for technology transfer available via universities and research institutes (Tymoshenko, 2014).

The Portugal's Innovation Relay Centre (IRC Portugal (ISQ) manages one of the two information centres in Portugal and supports innovation in the framework of transnational cooperation on the transfer of technology to Europe (Chernenko, 2011).

Great Britain has a significant experience in public guaranteeing of bank loans. The state guarantees a return of $70 \%$ of loans granted to venture capital firms, and reimburses up to $50 \%$ of all innovation costs and subsidizes small innovative firms. The UK has a welldeveloped network of over 325 business incubators, regulated by the Office for Business Incubators. The UK Business Incubation provides a wide range of services from the creation of a company and its leasing transfer to consulting, financial, legal, employment services, etc.

Priorities ofUKinnovationinvolvemedicaltechnology, renewable energy, nanoelectronics, communications infrastructure protection, biotechnology, intelligent management system, environmental management. The country attaches great importance to the development and advancement of high-tech ecological services in the world market (Yepifanova, 2013).

In the Netherlands, there is the Mkbinnovatiestimulering Regio en Topsectoren (MIT) program for stimulating innovation in small businesses in the regions and "top sectors." According to this program, the Netherlands Ministry of Economic Affairs cooperates with local authorities to encourage innovation in small businesses.

The "top" or key sectors in the Netherlands include agro-industry, horticulture and seed production, high technology, energy, logistics, creative economy, health and life sciences, and the chemical industry. The Government of the Netherlands has determined these sectors as providing the country with competitive advantages in the global market and as priorities for development. The Top Consortia for Knowledge and Innovation (TKIs) work in each sector, bringing together entrepreneurs and academics in a particular industry and partially funded by the government.

The innovation promotion program contains the following instruments:

- consulting projects (obtaining consultations from a scientific institution or an independent consulting company);

- projects of technical and economic testing of innovative products (determination of technical and economic risks for the innovation proposed); 
- collaboration in research and development (sharing knowledge with independent partners to implement innovation in products, processes or services);

- vouchers of knowledge (possibility of consulting in a scientific institution).

Top Consortia also present two instruments, such as broker services for innovation and networking (Kovalchuk, 2015).

\section{Conclusion}

Therefore, the global financing of innovative small businesses has demonstrated that financial support of innovative small businesses is based on its targeting and has different sources of financing. Moreover, the capitalization of small business intangible assets in the form of intellectual performance is a basic condition for the transition to a developed economy and provides a wide range of financial instrument applications in a market economy. Capitalizing intangible assets for over half a century, the United States, Japan, China, Great Britain, France, Germany, the Netherlands, and a number of other countries have managed to effectively implement the financial support of innovative small businesses, to maintain this process by state strategy, government orders, to involve private capital, to engage small business resources in market turnover and to build a powerful innovative economy. The economic world communities' policy, focused on the primary financial encouragement of innovative small businesses, leading scientific research that creates intellectual property, contributed to this as well.

\section{References:}

On Innovation Activity (Law of Ukraine of July 04, 2002). Retrieved from: http://zakon.rada.gov.ua/laws/ show/40-15 (in Ukrainian)

The Cabinet of Ministers of Ukraine. Pro zatverdzhennia Derzhavnoi tsilovyi prohramy rozvytku systemy informatsiino-analitychnoho zabezpechennia realizatsii derzhavnoi innovatsiinoi polityky ta monitorynhu stanu innovatsiinoho rozvytku ekonomiky [On approval of the State target program for the development of the information and analytical support system for the implementation of the state innovation policy and monitoring the status of innovative economic development]. Resolution no. 439 of May 7, 2008. Retrieved from: http://zakon.rada.gov.ua/laws/show/439-2008-\%D0\%BF (in Ukrainian)

Yevropeiska khartiia malykh pidpryiemstv [European charter for small enterprises]. Retrieved from: http://zakon.rada.gov.ua/laws/show/994_860 (in Ukrainian)

Malyi biznes: kreditovaniye malogo biznesa [Small businesses: small business loans]. Retrieved from: http://www.kreditbusiness.ru/foregnbusiness (in Russian)

Razvitie ekonomiki Kitaia: stanovlenie malogo predprinimatelstva [Development of the Chinese economy: Small business development]. Retrieved from: http://www.kreditbusiness.ru/foreignbusiness/71-razvitiejekonomikikitaja-stanovlenie-malogo.html (in Russian)

Ekonomika v Singapure: znachenie i rol malogo predprinimatelstva [Singapore economy: Importance and role of small businesses]. Retrieved from: http://www.kreditbusiness.ru/foreignbusiness/72-jekonomika-v-singapureznachenie-i-rol-malogo.html (in Russian)

Maloe predprinimatelstvo i biznes $\mathrm{v}$ Ispanii [Small enterprises and businesses in Spain]. Retrieved from: http://www.kreditbusiness.ru/foreignbusiness/30-maloe-predprinimatelstvoi-biznes-v-ispanii.html (in Russian)

Financing Programmes for SMEs. EUbusiness - European Union business news search and analysis. Retrieved from: http://www.eubusiness.com/topics/euro/SMEs/?searchterm=financing\%20 SME

Kornilova, I. (2014). Svitovyi dosvid finansovoi pidtrymky innovatsiinoho rozvytku [World experience of financial support for innovation development]. Visnyk Kyiivskoho natsionalnoho universytetu imeni Tarasa Shevchenka, 8(161), 30-36. (in Ukrainian)

Doslidzhennia: obgruntuvannia napriamiv rozvytku innovatsiinoho pidpryiemnytstva z urakhuvanniam svitovoho dosvidu [Research: substantiation of areas of innovative business development taking into account world experience]. Retrieved from: http://old.niss.gov.ua/Monitor/September/10.htm (in Ukrainian)

Tymoshenko, O. V. (2014). Zakordonnyi dosvid derzhavnoho rehuliuvannia ta pidtrymky maloho ta serednoho pidpryiemnytstva [Foreign experience of state regulation and support of small and medium entrepreneurship]. Investytsii: praktyka ta dosvid, 13, 142-146. (in Ukrainian)

Chernenko, S. M. (2011). Zarubizhnyi dosvid rozvytku maloho pidpryiemnytstva v konteksti innovatsiinoho rozvytku ekonomiky [Foreign experience of small business development in the context of innovative development of the economy]. Ekonomichni innovatsii, 45, 243-252. (in Ukrainian)

Yepifanova, I. Yu. (2013). Svitovyi dosvid finansuvannia innovatsiinoi diialnosti pidpryiemstv [World experience in financing innovation activity of enterprises]. Visnyk natsionalnoho universytetu "Lvivska politekhnika", 776, 249-254. (in Ukrainian)

Kovalchuk, A. (2015). Instrumenty polityky shchodo maloho ta serednoho pidpryiemnytstva: mizhnarodnyi dosvid [Small and Medium Enterprise Policy Tools: International Experience]. Kyiv: USAID «Liderstvo v ekonomichnomu vriaduvanni». (in Ukrainian) 